\title{
Contractor's Selection Criteria in Construction Works in Pakistan
}

\author{
Noor ul Islam Soomro \\ Department of Civil Engineering \\ Mehran University of Engineering and Technology Jamshoro \\ Sindh, Pakistan \\ noorsoomro93@gmail.com
}

\section{Nafees Ahmed Memon}

Department of Civil Engineering

Mehran University of Engineering and Technology

Jamshoro Sindh, Pakistan

nafees.memon@faculty.muet.edu.pk

\author{
Aftab Hameed Memon \\ Department of Civil Engineering \\ Quaid-e-Awam University of Engineering, Science and \\ Technology, Nawabshah, Sindh, Pakistan \\ aftabm78@hotmail.com \\ Kashif Rafique Memon \\ Department of Civil Engineering \\ Mehran University of Engineering and Technology \\ Jamshoro Sindh, Pakistan \\ kashif.memon33@gmail.com
}

\begin{abstract}
The contractor is the primary stakeholder in materializing a project concept. For the successful completion of any project, it is compulsory for the contractor to have relevant experience. The selection of the appropriate contractor depends on various criteria. This study aims to study these selection criteria. Based on 71 questionnaire forms received from representatives of contractor, consultant and client firms involved in execution works of construction activities it is found that quality, bid amount, technical capability, financial stability, and experience are five commonly adopted criteria for contractor selection in construction works in Pakistan. On the other hand, quality, technical capability, financial stability, equipment availability, and management capability are reported as the top five effective criteria for appropriate contractor selection for any construction project.
\end{abstract}

Keywords-contractor selction; selection criteria; Pakistan; Sindh; construction works

\section{INTRODUCTION}

The success of a project depends on the performance of the contractor, hence its selection is essential. The selection of the right contractor reduces cost while assuring high quality work [1]. A research carried out in Hong Kong identified five critical factors for project success: initiation and transmission of conflict resolution, energy, resource sharing among project participants and responsibilities have been defined clearly [2]. In traditional contracting, the contractors are mostly selected based on lowest bid criterion which often results in declination of quality, cost, and completion time of the project. Thus, it is essential to select a suitable contractor for the project for achieving effective performance and successful completion. This paper focuses on studying the contractor selection criteria adopted in construction works in Pakistan. This paper identified the level of adoption for selection criteria of contractors and the level of effectiveness of each criterion. The level of adoption references to the occurrence, i.e. how common each criterion is used in construction industry, while the level of effectiveness defines the importance of the criteria.

\section{CONTRACTOR SELECTION CRITERIA}

For the success of any construction work, contractor selection is very imperative phase. A selection criterion is involved in judging and measuring the potential of contractors. The skills of contractors are judged and calculated. Some common criteria considered in contractor selection are:

- Technical capacity: Contractors must have the capability of completing project activities successfully [3].

- Experience: Experience plays an important role in performing any task with ease and perfection. Hence, it is essential to select the contractor based on its relevant work experience in past [3].

- Management capacity: Planning, organizing and handling of project express the management capability of the contractor [3].

- Financial stability: Overall financial position and capability must be examined based on the cash flow of the contractor [3].

- Past performance: Past performance should be considered for time, quality, and cost control requirements [4].

- Past relationship: Clients need to gather all the information regarding the contractor and evaluate its past affiliation which contributes in construction activities [4].

- Reputation: Project manager must have an opinion about the contractor's past performance and reputation regarding the success in projects' completion [4].

- Occupational health and safety: Contractors must apply occupational health and safety principles [3]. 
- Quality: The contractor must be capable to maintain the desirable quality standards [3].

- Organizational skills: Focus on the effective utilization of the required resources with teamwork creating environment for team work while directly reduce the level of individual stress.

- Current workload: It refers to the present workload of the running project [3].

- Equipment: It should be ensured that the contractor has the sufficient equipment required for the project [6].

- Human resources: Human resource management deals with employee selection, recruiting, providing orientation, training, and development, appraising employee performance, motivating employees, deciding compensation, and ensuring safety, welfare, health and incompliance with labor laws [6].

- Project-specific requirements: They are some specific requirements necessary to ensure the specific project's success. They are meant to align the project resources with the objectives of the owner. The benefits of collecting project requirements include cost reduction, higher project success rate, enhanced stakeholder communication and effective management of change [5].

- Business location: The location of a business is the place where it is situated and it refers to the nearby locations where all the requirements can be achieved successfully.
The owner should look at the advantages which each area has to offer [5].

- Bid amount: It is colloquially known as a "Bid" in markets, and is often lower than the asking price [4].

If the contractor is technically sound and has adequate experience, equipment availability, and personnel to satisfy the client, it can achieve the successful completion of the project. Further, the financial soundness of the contractor may help to achieve the best quality and project success within the desired time. If the contractor management capability is high, then it is easy for the contractor to deal with technical personnel with experience, quality, and management and project management capabilities. If the contractor's reputation is high then past performance and past relationships are considered by the clients making the contractor favorable for more awarding contracts. The selection of a suitable contractor is the key to project success by awarding the contracts to the lowest price with multi-criteria selection practices. Both technical and financial criteria are considered in a multi criteria process. Most changes occur by local official authorities and are useful for maintaining construction quality. A study of Gaza strip showed that central bidding committee provides a fair bid evaluation process, with equal opportunities to all bidders, and suitable responsibility [4]. Authors in [3] revealed that financial soundness, technical ability, management capability and health and safety are major criteria for selecting a contractor. Various researchers have highlighted different criteria for selecting the appropriate contractor as shown in Table I.

TABLE I. CONTRACTOR SELECTION CRITERIA

\begin{tabular}{|l|c|c|c|c|c|c|c|c|c|c|c|c|c|c|c|c|c|}
\hline & {$[3]$} & {$[4]$} & {$[5]$} & {$[6]$} & {$[8]$} & {$[9]$} & {$[10]$} & {$[11]$} & {$[\mathbf{1 2}]$} & {$[\mathbf{1 3}]$} & {$[\mathbf{1 4}]$} & {$[\mathbf{1 5}]$} & {$[\mathbf{1 6}]$} & {$[\mathbf{1 7}]$} & {$[\mathbf{1 8}]$} & {$[\mathbf{1 9}]$} & {$[\mathbf{2 0}]$} \\
\hline Experience & $\checkmark$ & $\checkmark$ & $\checkmark$ & & $\checkmark$ & $\checkmark$ & $\checkmark$ & $\checkmark$ & $\checkmark$ & $\checkmark$ & $\checkmark$ & $\checkmark$ & & $\checkmark$ & $\checkmark$ & $\checkmark$ & $\checkmark$ \\
\hline Technical capability & $\checkmark$ & $\checkmark$ & $\checkmark$ & & & & $\checkmark$ & & $\checkmark$ & $\checkmark$ & $\checkmark$ & $\checkmark$ & $\checkmark$ & $\checkmark$ & & $\checkmark$ & $\checkmark$ \\
\hline Financial stability & $\checkmark$ & $\checkmark$ & $\checkmark$ & $\checkmark$ & $\checkmark$ & $\checkmark$ & $\checkmark$ & $\checkmark$ & $\checkmark$ & $\checkmark$ & $\checkmark$ & $\checkmark$ & $\checkmark$ & $\checkmark$ & $\checkmark$ & $\checkmark$ & $\checkmark$ \\
\hline Management capability & $\checkmark$ & $\checkmark$ & $\checkmark$ & $\checkmark$ & & $\checkmark$ & $\checkmark$ & $\checkmark$ & $\checkmark$ & & $\checkmark$ & $\checkmark$ & $\checkmark$ & $\checkmark$ & & $\checkmark$ & $\checkmark$ \\
\hline Past relationship & & & & $\checkmark$ & & & & & & $\checkmark$ & & & & & & $\checkmark$ & \\
\hline Past performance & & $\checkmark$ & $\checkmark$ & $\checkmark$ & $\checkmark$ & $\checkmark$ & & & & $\checkmark$ & $\checkmark$ & $\checkmark$ & & $\checkmark$ & $\checkmark$ & $\checkmark$ & $\checkmark$ \\
\hline Occupational health and safety & $\checkmark$ & $\checkmark$ & $\checkmark$ & $\checkmark$ & $\checkmark$ & & $\checkmark$ & $\checkmark$ & $\checkmark$ & & $\checkmark$ & $\checkmark$ & $\checkmark$ & & $\checkmark$ & $\checkmark$ & $\checkmark$ \\
\hline Reputation & & & $\checkmark$ & $\checkmark$ & & & $\checkmark$ & & & $\checkmark$ & & & $\checkmark$ & $\checkmark$ & & $\checkmark$ & \\
\hline Organizational skills & & $\checkmark$ & & & & $\checkmark$ & & & & & & $\checkmark$ & & & $\checkmark$ & & \\
\hline Quality & $\checkmark$ & & $\checkmark$ & $\checkmark$ & $\checkmark$ & & & $\checkmark$ & $\checkmark$ & $\checkmark$ & $\checkmark$ & & & & $\checkmark$ & $\checkmark$ & \\
\hline Environmental aspects & & & & & & & & & & & $\checkmark$ & & & & & & $\checkmark$ \\
\hline Current workload & $\checkmark$ & & $\checkmark$ & & & & & & & & & & & $\checkmark$ & & \\
\hline Equipment & & $\checkmark$ & & & & & & & & & & & & & & & \\
\hline Human resources/ managerial resources & & $\checkmark$ & $\checkmark$ & & & & & & & & & & & & & $\checkmark$ & $\checkmark$ \\
\hline Project-specific requirements & & & $\checkmark$ & & & & & & $\checkmark$ & & & & & & & & \\
\hline Business location & & & $\checkmark$ & & & & & & & & & & & & & \\
\hline Bid amount & & & & $\checkmark$ & & & & & & & & & $\checkmark$ & & & $\checkmark$ \\
\hline
\end{tabular}

\section{DATA COLLECTION AND ANALYSIS RESULTS}

The data for this study were gathered through a survey amongst construction practitioners. Out of 120 sent survey forms, 71 were received from various professionals in relevant fields. Prior to the analysis of the gathered data, the reliability of the data was assessed by Cronbach's alpha computed with statistical software package SPSS. Cronbach's alpha for the level of adoption of the criteria is 0.949 while the alpha for the level of effectiveness is 0.859 . The value of alpha for adoption level and level of effectiveness are higher than 0.7 (the alpha value is considered satisfactory if it is greater than 0.7 [7]), hence, the data are considered reliable and can be considered for further analysis and drawing conclusions. The forms were analyzed statistically and the results are discussed below.

\section{A. Respondents Profile}

The respondents participating in the survey had strong technical profile and were employed in the construction sector. The characteristics of the participants are summarized in Table 
II, from which it can be observed that the majority of the participants (33 out of 71) are representatives of client firms while at the second level, 24 participants are engaged in contractor companies, and 14 participants are working with consultants. Among these respondents, 36 have completed civil engineering education, 26 have finished a Master, 6 have a diploma, while 3 are $\mathrm{PhD}$ holders. These respondents are working for several years in construction works with experience spanning from less than 5 years (49) to more than 20 years (5). Among these participants, 13 are involved in project executions with contract sum above Rs. 3000M, 14 are working in projects costing Rs. $400 \mathrm{M}$ to $3000 \mathrm{M}$ and the other practitioners are working in projects costing below Rs. 400M. Eight participants are directors of their companies, 11 are working at a managerial level, 28 are resident and planning engineers, while 24 respondents are site supervisors and site engineers.

TABLE II. PROFILE OF RESPONDENTS

\begin{tabular}{|c|c|c|c|}
\hline & Frequency & Percent & $\begin{array}{c}\text { Cumulative } \\
\text { percent }\end{array}$ \\
\hline \multicolumn{4}{|l|}{ Organization type } \\
\hline Consultant & 14 & 19.7 & 19.7 \\
\hline Contractor & 24 & 33.8 & 53.5 \\
\hline Client & 33 & 46.5 & 100.0 \\
\hline \multicolumn{4}{|l|}{ Education level } \\
\hline Diploma & 6 & 8.5 & 8.5 \\
\hline Degree & 36 & 50.7 & 59.2 \\
\hline Master & 26 & 36.6 & 95.8 \\
\hline $\mathrm{PhD}$ & 3 & 4.2 & 100.0 \\
\hline \multicolumn{4}{|l|}{ Experience level } \\
\hline $0-5$ years & 49 & 69.0 & 69.0 \\
\hline $06-10$ years & 9 & 12.7 & 81.7 \\
\hline $11-15$ years & 5 & 7.0 & 88.7 \\
\hline $16-20$ years & 3 & 4.2 & 93.0 \\
\hline $21-25$ years & 2 & 2.8 & 95.8 \\
\hline more than 25 years & 3 & 4.2 & 100.0 \\
\hline \multicolumn{4}{|l|}{ Project size (Rs.) } \\
\hline Less than Rs. 20M & 18 & 25.4 & 25.4 \\
\hline $20 \mathrm{M}-50 \mathrm{M}$ & 16 & 22.5 & 47.9 \\
\hline $50 \mathrm{M}-150 \mathrm{M}$ & 4 & 5.6 & 53.5 \\
\hline $150 \mathrm{M}-400 \mathrm{M}$ & 6 & 8.5 & 62.0 \\
\hline $400 \mathrm{M}-800 \mathrm{M}$ & 8 & 11.3 & 73.2 \\
\hline $800 \mathrm{M}-1800 \mathrm{M}$ & 5 & 7.0 & 80.3 \\
\hline $1800 \mathrm{M}-3000 \mathrm{M}$ & 1 & 1.4 & 81.7 \\
\hline Above $3000 \mathrm{M}$ & 13 & 18.3 & 100.0 \\
\hline
\end{tabular}

\section{B. Level of Adoption of Contractor's Selection Criteria}

The participants responding in the survey process were required to rate the adoption level of various criteria of contractor's selection considered by their respective companies. The respondents were asked to indicate the level of adoption using a 5 point scale where $1=$ never, $2=$ sometimes, $3=$ moderately, $4=$ usually and $5=$ always. Mean value, standard deviation, and ranking obtained from statistical analysis of the data collection for these criteria are presented in Table III. It can be seen that quality with mean value of 3.90 and standard deviation 1.232 is reported as the most commonly adopted criterion and is ranked first by the participants. Bid amount with mean value of 3.87 and standard deviation 1.120 is placed second and technical capability is third with a mean value of 3.87 and standard deviation 1.170. The participants were also asked to mark the level of effectiveness of all these criteria.

TABLE III. CONTRACTOR SELECTION CRITERIA ADOPTION LEVEL

\begin{tabular}{|c|c|c|c|c|c|c|c|c|}
\hline \multirow{2}{*}{$\begin{array}{l}\text { Contractor selection } \\
\text { criteria }\end{array}$} & \multicolumn{5}{|c|}{ Frequency for scale } & \multirow{2}{*}{ ह } & \multirow{2}{*}{$\stackrel{\theta}{\dot{n}}$} & \multirow{2}{*}{ 范 } \\
\hline & 1 & 2 & 3 & 4 & 5 & & & \\
\hline Quality & 6 & 3 & 12 & 21 & 29 & 3.90 & 1.232 & 1 \\
\hline Bid amount & 3 & 6 & 13 & 24 & 25 & 3.87 & 1.120 & 2 \\
\hline Technical capability & 3 & 8 & 11 & 22 & 27 & 3.87 & 1.170 & 3 \\
\hline Financial stability & 4 & 8 & 14 & 18 & 27 & 3.78 & 1.229 & 4 \\
\hline Experience & 8 & 13 & 4 & 13 & 33 & 3.70 & 1.487 & 5 \\
\hline Past performance & 3 & 10 & 14 & 23 & 21 & 3.69 & 1.166 & 6 \\
\hline Equipment & 4 & 12 & 10 & 27 & 18 & 3.60 & 1.200 & 7 \\
\hline $\begin{array}{l}\text { Management } \\
\text { capability }\end{array}$ & 3 & 11 & 17 & 22 & 18 & 3.57 & 1.154 & 8 \\
\hline Reputation & 5 & 9 & 17 & 21 & 19 & 3.56 & 1.215 & 9 \\
\hline Organizational skills & 5 & 9 & 17 & 21 & 19 & 3.56 & 1.215 & 10 \\
\hline $\begin{array}{l}\text { Project-specific } \\
\text { requirements }\end{array}$ & 3 & 13 & 16 & 23 & 16 & 3.50 & 1.157 & 11 \\
\hline $\begin{array}{l}\text { Human resources/ } \\
\text { managerial resources }\end{array}$ & 6 & 14 & 14 & 19 & 18 & 3.40 & 1.293 & 12 \\
\hline Current workload & 7 & 11 & 19 & 18 & 16 & 3.35 & 1.266 & 13 \\
\hline $\begin{array}{l}\text { Environmental } \\
\text { aspects }\end{array}$ & 8 & 12 & 17 & 18 & 16 & 3.30 & 1.304 & 14 \\
\hline $\begin{array}{l}\text { Occupational health } \\
\text { and safety }\end{array}$ & 7 & 11 & 24 & 15 & 14 & 3.25 & 1.227 & 15 \\
\hline Business location & 7 & 15 & 16 & 22 & 11 & 3.21 & 1.229 & 16 \\
\hline Past relationship & 5 & 16 & 21 & 20 & 9 & 3.16 & 1.133 & 17 \\
\hline
\end{tabular}

TABLE IV. EFFECTIVENESS LEVEL OF CONTRACTOR SELECTION CRITERIA

\begin{tabular}{|c|c|c|c|c|c|c|c|c|}
\hline \multirow{2}{*}{$\begin{array}{l}\text { Contractor selection } \\
\text { criteria }\end{array}$} & \multicolumn{5}{|c|}{ Frequency for Scale } & \multirow{2}{*}{ Е } & \multirow{2}{*}{$\stackrel{\rho}{\dot{s}}$} & \multirow{2}{*}{ 幽 } \\
\hline & 1 & 2 & 3 & 4 & 5 & & & \\
\hline Quality & 4 & 2 & 17 & 18 & 30 & 3.95 & 1.139 & 1 \\
\hline Experience & 6 & 3 & 11 & 19 & 32 & 3.95 & 1.247 & 2 \\
\hline Technical capability & 4 & 10 & 11 & 17 & 29 & 3.80 & 1.271 & 3 \\
\hline Financial stability & 5 & 8 & 9 & 24 & 25 & 3.78 & 1.241 & 4 \\
\hline Equipment & 4 & 7 & 12 & 26 & 22 & 3.77 & 1.161 & 5 \\
\hline Management capability & 2 & 8 & 17 & 23 & 21 & 3.74 & 1.091 & 6 \\
\hline Bid amount & 3 & 8 & 15 & 27 & 18 & 3.69 & 1.103 & 7 \\
\hline Reputation & 3 & 7 & 22 & 20 & 19 & 3.63 & 1.111 & 8 \\
\hline Current workload & 4 & 8 & 15 & 28 & 16 & 3.61 & 1.125 & 9 \\
\hline Past performance & 3 & 11 & 15 & 24 & 18 & 3.60 & 1.152 & 10 \\
\hline Organizational skills & 2 & 11 & 18 & 23 & 17 & 3.59 & 1.102 & 11 \\
\hline $\begin{array}{l}\text { Project-specific } \\
\text { requirements }\end{array}$ & 3 & 8 & 20 & 28 & 12 & 3.53 & 1.039 & 12 \\
\hline $\begin{array}{l}\text { Human resources/ } \\
\text { managerial resources }\end{array}$ & 5 & 10 & 16 & 24 & 16 & 3.50 & 1.193 & 13 \\
\hline Past relationship & 4 & 13 & 25 & 20 & 9 & 3.23 & 1.075 & 14 \\
\hline Business location & 4 & 16 & 20 & 21 & 10 & 3.23 & 1.127 & 15 \\
\hline $\begin{array}{l}\text { Occupational health and } \\
\text { safety }\end{array}$ & 4 & 17 & 18 & 22 & 10 & 3.23 & 1.139 & 16 \\
\hline Environmental aspects & 6 & 15 & 17 & 23 & 10 & 3.22 & 1.185 & 17 \\
\hline
\end{tabular}

The respondents were asked to indicate the level of effectiveness using a 5 point scale as $1=$ not effective, $2=$ less effective, $3=$ moderately effective, $4=$ very effective and $5=$ extremely effective. Analysis of the data was performed with mean value and standard deviation calculation and is presented in Table IV. It can be seen that that quality with mean value of 3.95 and standard deviation 1.139 is reported as the most effective criterion, with technical capability and financial 
stability following with mean value of 3.8 and 3.78 respectively. Equipment availability and management capability were at the fourth and fifth place.

\section{CONCLUSION}

This paper focused on highlighting the contractor's selection criteria adopted in construction works in Pakistan. This aim was achieved through a survey of construction practitioners using a form based on 17 criteria identified in the literature. Mean value and standard deviation analysis of the 71 survey forms received revealed that quality, bid amount, technical capability, financial stability and experience are common criteria adopted in construction projects of Pakistan for selecting the most appropriate contractor. The study also highlighted that quality, technical capability, financial stability, equipment availability, and management capability are the most effective criteria for selecting a contractor for any construction project. The findings of this study will be very useful for consultants and clients in order to select a suitable contractor for construction works.

\section{REFERENCES}

[1] A. P. C. Chan, A. P. L. Chan, "Key performance indicators for measuring construction success", Benchmarking: an International Journal, Vol. 11, No. 2, pp. 203-221, 2004

[2] A. P. C. Chan, D. W. M. Chan, Y. H. Chiang, B. S. Tang, E. H. W. Chan, K. S. Ho, "Exploring critical success factors for partnering in construction projects", Journal of Construction Engineering and Management, Vol. 130, No. 2, pp. 188-198, 2004

[3] Z. Hatush, M. Skitmore, "Criteria for contractor selection", Construction Management \& Economics, Vol. 15, No. 1, pp. 19-38, 1997

[4] A. Enshassi, S. Mohamed, Z. Modough, "Contractors' selection criteria: opinions of Palestinian construction professionals", International Journal of Construction Management, Vol. 13, No. 1, pp. 19-37, 2013

[5] S. T. Ng, R. M. Skitmore, "Contractor selection criteria: a cost-benefit analysis”, IEEE Transactions on Engineering Management, Vol. 48, No. 1, pp. 96-106, 2001

[6] E. Palaneeswaran, M. M. Kumaraswamy, "Contractor selection for design/build projects", Journal of Construction Engineering and Management, Vol. 126, No. 5, pp. 331-339, 2000

[7] M. A. Munir, M. A. Zaheer, M. Haider, M. Z. Rafique, M. A. Rasool, M. S. Amjad, "Problems and barriers affecting total productive maintenance implementation", Engineering, Technology \& Applied Science Research, Vol. 9, No. 5, pp. 4818-4823, 2019

[8] J. S. Russell, M. J. Skibniewski, "Decision criteria in contractor prequalification", Journal of Management in Engineering, Vol. 4, No. 2, pp. 148-164, 1998

[9] G. D. Holt, P. O. Olomolaiye, F. C. Harris, "Evaluating prequalification criteria in contractor selection", Building and Environment, Vol. 29, No. 4, pp. 437-448, 1994

[10] Z. Hatush, M. Skitmore,"Contractor selection using multicriteria utility theory: an additive model", Building and Environment, Vol. 33, No. 2-3, pp. 105-115, 1998

[11] L. F. Alarcon, C. Mourgues, "Performance modeling for contractor selection", Journal of Management in Engineering, Vol. 18, No. 2, pp. 52-60, 2002

[12] E. K. Zavadskas, T. Vilutiene, "A multiple criteria evaluation of multifamily apartment block's maintenance contractors: I-Model for maintenance contractor evaluation and the determination of its selection criteria”, Building and Environment, Vol. 41, No. 5, pp. 621-632, 2006

[13] D. Singh, R. L. Tiong, "Contractor selection criteria: Investigation of opinions of Singapore construction practitioners", Journal of Construction Engineering and Management, Vol. 132, No. 9, pp. 9981008,2006
[14] F. Waara, J. Brochner, "Price and nonprice criteria for contractor selection", Journal of Construction Engineering and Management, Vol. 132, No. 8, pp. 797-804, 2006

[15] H. Doloi, "Analysis of pre-qualification criteria in contractor selection and their impacts on project success", Construction Management and Economics, Vol. 27, No. 12, pp. 1245-1263, 2009

[16] G. V. Manideepak, A. Bhatla, B. Pradhan, "Methodologies for contractor selection in construction industry", ACSGE-2009, BITS Pilani, India, October 25-27, 2009

[17] D. J. Watt, B. Kayis, K. Willey, "The relative importance of tender evaluation and contractor selection criteria", International Journal of Project Management, Vol. 28, No. 1, pp. 51-60, 2010

[18] P. Jaskowski, S. Biruk, R. Bucon, "Assessing contractor selection criteria weights with fuzzy AHP method application in group decision environment", Automation in Construction, Vol. 19, No. 2, pp. 120-126, 2010

[19] Z. Morkunaite, V. Podvezko, V. Kutut, "Selection criteria for evaluating contractors of cultural heritage objects", Procedia Engineering, Vol. 208, pp. 90-97, 2017

[20] D. N. A. Ayettey, H. Danso, "Contractor selection criteria in Ghanaian construction industry: Benefits and challenges", Journal of Building Construction and Planning Research, Vol. 6, pp. 278-297, 2018 